Мостовенко Н. А., к.е.н., доцент Коробчук Т. І., к.е.н., доцент Приступа Ю. В., здобувач

Луцький національний технічний університет м. Луцьк, Волинська область, Україна

DOI: https://doi.org/10.30525/978-9934-26-018-6-27

\title{
ЗАБЕЗПЕЧЕНІСТЬ СУБ'ЄКТІВ РИНКУ КРЕДИТНИМИ ПОСЛУГАМИ БАНКІВ: АНАЛІТИЧНИЙ АСПЕКТ
}

Як відомо, економічне зростання неможливо забезпечити поза ринком позикових ресурсів. Фінансово-кредитна підтримка стимулює ефективну діяльність будь-якого підприємства, домашнього господарства та держави. Рівень надання кредитних послуг відіграє ключову роль у розвитку національної економіки. Кредитні послуги банки нині надають підприємствам усіх форм власності, населенню, центральним і місцевим органам влади та іншим банкам, об'єднанням співвласників багатоквартирних будинків та житлово-будівельним кооперативам. Дані послуги призначаються банківськими установами для задоволення різних за термінами потреб клієнтів у грошових ресурсах. Серед потреб виділяють: формування і збільшення основного та оборотного капіталу, витрати на споживчі потреби, фінансування операцій спекулятивного характеру тощо. Відповідно актуальною $\epsilon$ 
аналітична оцінка рівня забезпеченості суб'єктів ринку кредитними послугами банків, як переважаючих фінансових посередників.

Кредитний ринок - найрозвиненіша частина фінансового ринку, що аргументується його високою часткою, порівняно 3 іншими сегментами. На вітчизняну банківську систему в останні роки припадає значна частина ринку кредитних послуг, що становлять кредитні портфелі банків та банківської системи України. Проаналізуємо динаміку кредитів, наданих домогосподарствам, корпоративному сектору та іншим резидентам в Україні за даними табл. 1.

За даними таблиці спостерігаємо, що найбільша частка у 2005-2019 рр. традиційно припадала на кредити нефінансовим корпораціям: 60,443\%-82,320\%. Динаміку кредитів, наданих цим суб'єктам ринку, можна оцінити за допомогою рис. 1. Слід зауважити, що найбільше відносне відхилення у розмірі 70,33\% припадає на 2007-2008pp., після чого річний приріст максимально сягав $14,89 \%$.

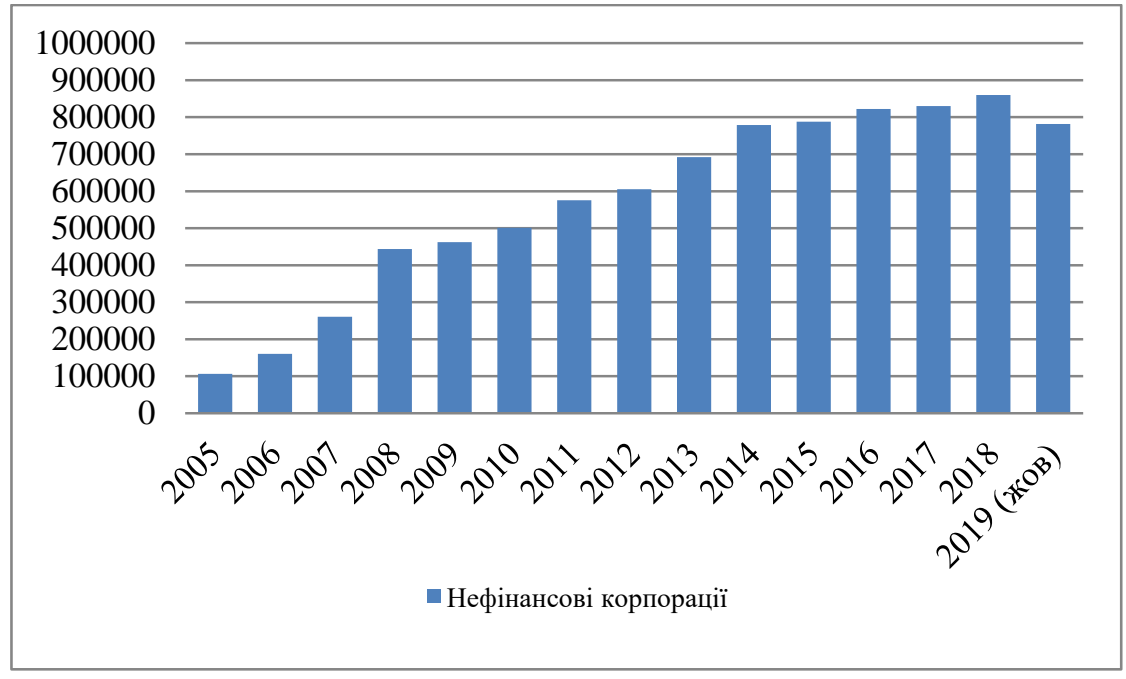

Рис. 1. Динаміка кредитів, наданих нефінансовим корпораціям, млн. грн. 


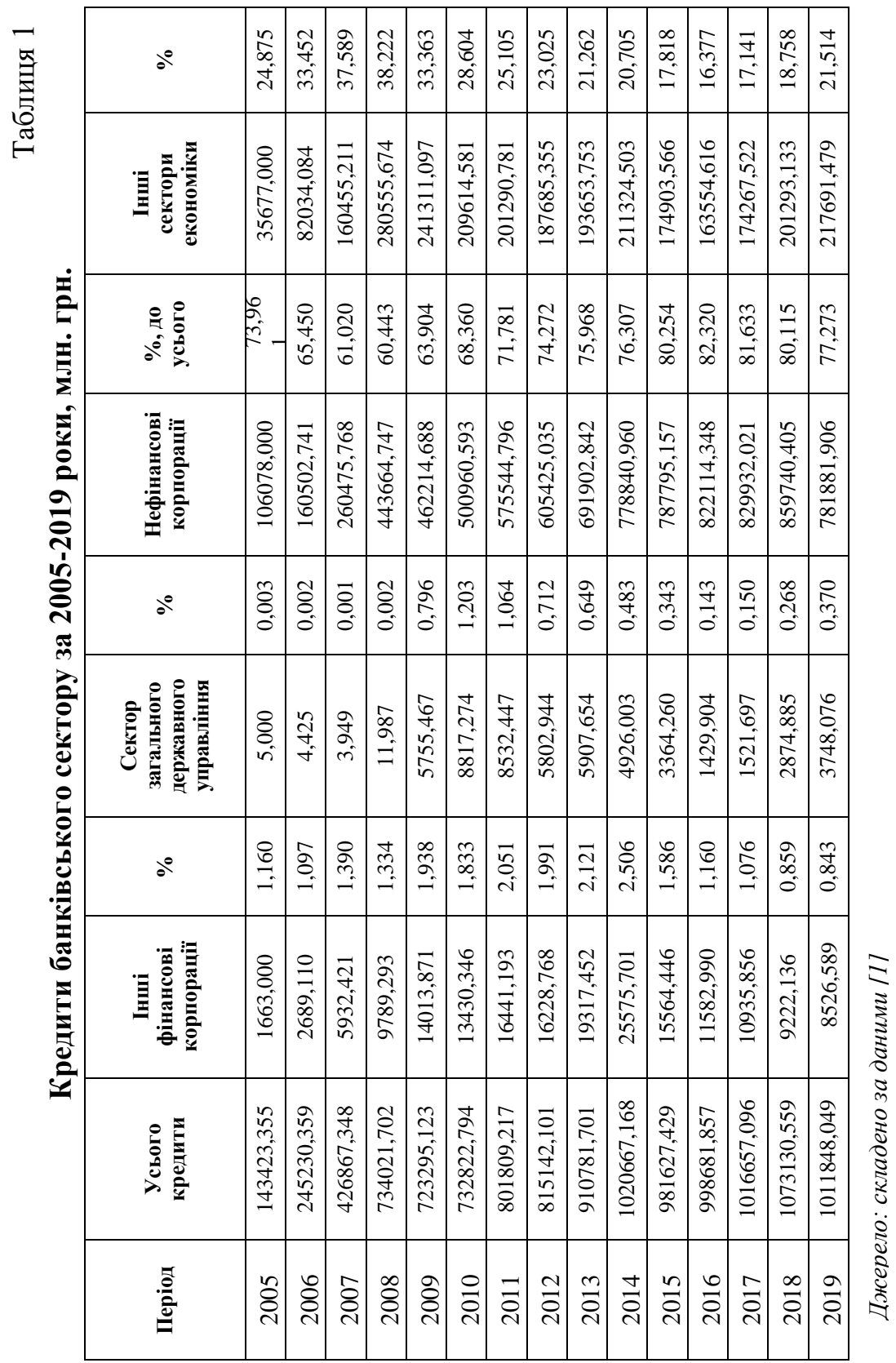


Наступним суб'єктом за величиною в загальному обсязі кредитування, за якими НБУ оприлюднює статистичні дані $€$ група суб'єктів під назвою «інші сектори економіки». У цей сектор включені домогосподарства та некомерційні організації, що їх обслуговують. Розглянемо більш детально динаміку кредитів наданих цим суб'єктам за допомогою рис. 2.

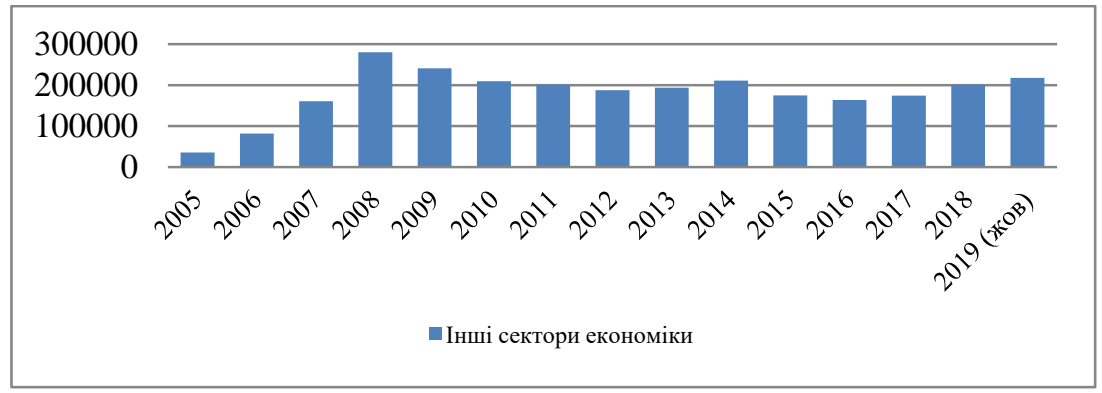

Рис. 2. Динаміка кредитів, наданих іншим секторам економіки, млн. грн.

У динаміці обсягів кредитування цього сегменту позичальників мають місце нестійка тенденція та коливання. Такий стан речей можна пояснити тим, що спроможність цих суб'єктів ринку обслуговувати борги за кредитами безпосередньо залежить від економічної ситуації в країні. Так, пік кредитування цього сегменту припадає на 2008 рік (280555,674 млн. грн.), до повторення якого ринок навіть не наближувався. Зміна цієї ситуації можлива лише за умови відновлення економічного зростання, без якого не буде збільшення рівня доходів населення, навіть за умови зниження кредитних ставок.

Звернемось до аналізу динаміки кредитів, наданих іншим фінансовим корпораціям (страховим компаніям, пенсійним фондам, кредитним установам тощо) за допомогою рис. 3 .

Як бачимо, лише до 2014 року спостерігалася стійка тенденція до зростання обсягів кредитування цього сегменту. На такий стан ринку мали значний вплив політична та економічна неста- 
більність в країні. Найвищий обсяг кредитних послуг надавався іншим фінансовим корпораціям у 2014 році (25575,701 млн. грн.).

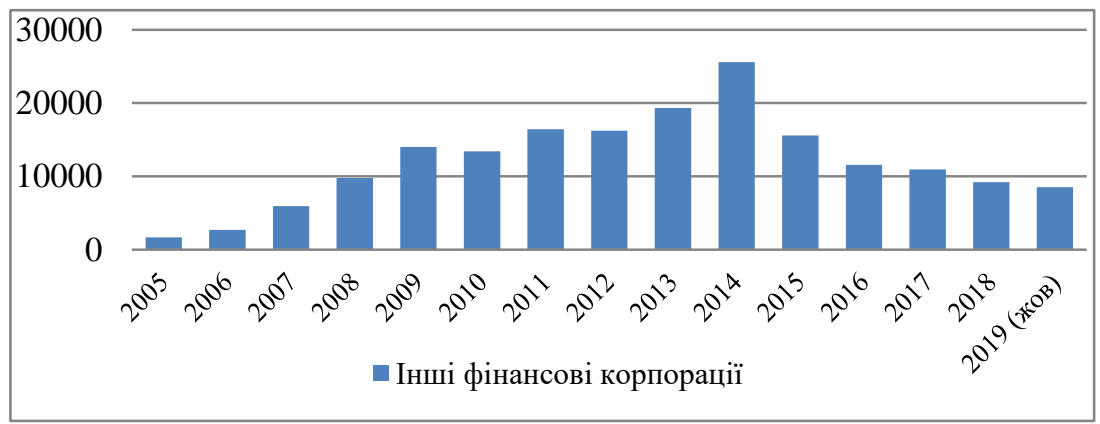

Рис. 3. Динаміка обсягу кредитування інших фінансових корпорацій, млн. грн.

Найменша частка серед споживачів кредитних послуг припадає на сектор загального державного управління (див. рис. 4). Як бачимо, різкий ріст кредитування спостерігається у 2009 році, що у абсолютному значенні склало 5743,48 млн. грн. порівняно із 2008 роком. I починаючи із 2010 року прослідковується стійка негативна тенденція до 2016 року, яка змінилася у 2017 році, після чого ринок, хоч і незначно, проте зростає.

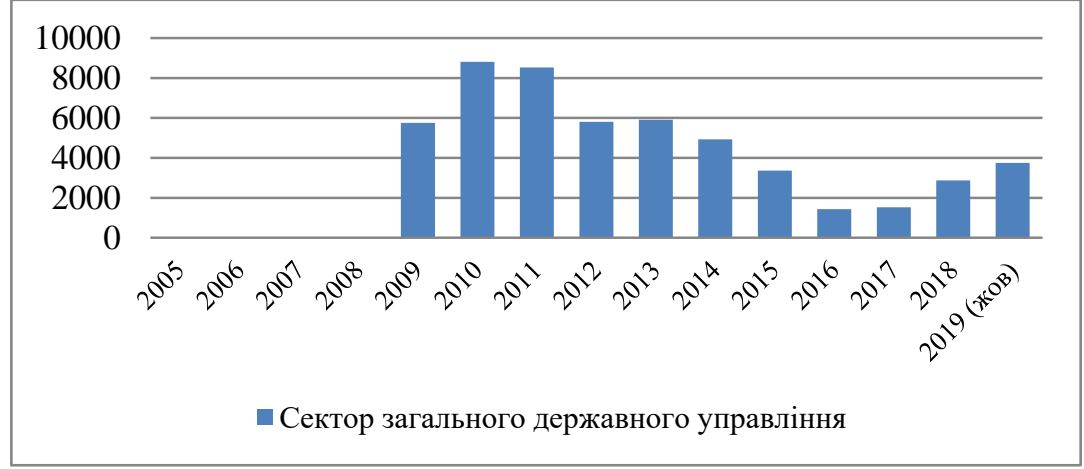

Рис. 4. Динаміка кредитів сектору державного управління, млн. Грн. 
Зазначимо, що питома вага кредитів, наданих державним нефінансовим корпораціям несуттєва. Загалом значного стабільного розвитку на кредитному ринку України набуває надання кредитних послуг сектору нефінансових корпорацій суб'єктів, що займаються виробничою діяльністю, реалізацією товарів, наданням послуг.

Таким чином, банківська система може задовольняти потреби господарюючих суб' єктів у позикових ресурсах у значно більших обсягах. Відновлення кредитування залежатиме від стану економічної системи, зростання ділової активності як нефінансових корпорацій так і добробуту домогосподарств.

\section{Література:}

1. Офіційний сайт Національного банку України. Грошово-кредитна статистика. URL: https://bank.gov.ua/ua/statistic/sector-financial/data-sector-financial \#1ms (дата звернення: 17.12.2020). 